UDC 71.06:86.376(2)

LBC 172.4:276.2(470+571)

\title{
FORMATION OF CULTURE OF PACIFICISM IN THE RUSSIAN SOCIETY: TRANSFORMATION OF IDEAS OF MENNONITES ${ }^{1}$
}

\author{
Olga Yu. Redkina \\ Volgograd State University, Volgograd, Russian Federation \\ Tatjana P. Nazarova \\ Volgograd State Agrarian University, Volgograd, Russian Federation
}

\begin{abstract}
The article considers the gradual transformation of certain aspects of the pacifist doctrine of the Mennonites under the influence of new farming conditions in the sparsely populated and inaccessible regions of the Russian Empire. Understanding of our duties to the state, which sheltered the persecuted community at the end of the $18^{\text {th }}$ century, guaranteed freedom of conscience (including the preservation of pacifism, among other things), this gave rise to a new attitude towards the Russian army, a desire to contribute to protecting the interests of the Fatherland in an acceptable form. The influence of Orthodox views on just wars, on the essence of serving the Fatherland on the patriotic views of the Mennonites of the Black Sea region seems probable. Remaining lawabiding citizens, during all wars the Mennonites found opportunities to provide comprehensive support to the Russian army without violating their religious beliefs - money donations, maintaining field hospitals, caring for wounded soldiers, providing transportation, food, and fodder. Reluctance to leave Russia in the $1870 \mathrm{~s}$ after the introduction of universal military service, it stimulated the Mennonites to seek a compromise with the Russian state, and led to the emergence of an alternative service for them in the forest teams. The widespread possession of cold steel and firearms, which was seized from them in 1914-1915, speaks about the transformation of certain aspects of the pacifist beliefs of the Mennonites living in Novorossia. The extreme conditions of the First World War and the Civil War gave an impetus to a more active revision of the pacifist beliefs by the Mennonites, to an individual decision on the form of service in the army or abandonment of it. The possession of weapons, the presence of significant arsenals in the communities will lead to the creation of self-defense units during the Civil war in Ukraine and the Crimea, to the combat participation of individual Mennonites on the side of the White and Red Armies. The majority of Mennonites will use the right not to serve in the army for religious reasons, enshrined in a decree of the SNK of the RSFSR in 1919.
\end{abstract}

Key words: culture of peace, pacifism, alternative service, Mennonites, Russian state.

УДК 71.06:86.376(2)

ББК 172.4:276.2(470+571)

\section{Әेे ФОРМИРОВАНИЕ КУЛЬТУРЫ ПАЦИФИЗМА В РОССИЙСКОМ ОБЩЕСТВЕ: ТРАНСФОРМАЦИЯ ИДЕЙ МЕННОНИТОВ ${ }^{1}$}

\author{
Ольга Юрьевна Редькина \\ Волгоградский государственный университет, г. Волгоград, Российская Федерация \\ Татьяна Павловна Назарова \\ Волгоградский государственный аграрный университет, г. Волгоград, Российская Федерация
}

Аннотация. В статье рассматривается постепенная трансформация отдельных сторон пацифистской доктрины меннонитов под влиянием новых условий ведения хозяйства в малозаселенных и труднодоступных регионах Российской империи. Понимание своих обязанностей перед государством, приютившим 
гонимую общину в конце XVIII в., гарантировавшим свободу совести (и сохранение пацифизма в том числе), порождало новое отношение религиозной общины меннонитов к армии России, желание внести свой вклад в защиту интересов Отчизны в приемлемой форме. Вероятным представляется влияние православных взглядов на справедливые войны, на сущность служения Отечеству на патриотические взгляды меннонитов Причерноморья. Оставаясь законопослушными гражданами, во время всех войн меннониты находили возможности оказать всестороннюю поддержку российской армии, не нарушая своих религиозных убеждений, - денежные пожертвования, содержание полевых госпиталей, уход за ранеными воинами, предоставление транспорта, провианта, фуража. Нежелание покидать Россию в 1870-х гг. после введения всеобщей воинской повинности стимулировало меннонитов на поиск компромисса с российским государством, привело к возникновению альтернативной службы для них в лесных командах. О трансформации отдельных сторон пацифистских убеждений меннонитов, проживавших в Новороссии, говорит широкое владение холодным и огнестрельным оружием, которое было изъято у них в 1914-1915 годах. Экстремальные условия Первой мировой и гражданской войн дали толчок к более активному пересмотру пацифистских убеждений, к индивидуальному решению о форме служения в армии или отказа от нее. Владение оружием, наличие значительных арсеналов в общинах приведет к созданию отрядов самообороны в годы гражданской войны на Украине и в Крыму, к боевому участию отдельных меннонитов на стороне Белой и Красной армий. Большая же часть меннонитов воспользуется правом не служить в армии по религиозным убеждениям, закрепленном декретом СНК РСФСР в 1919 году.

Ключевые слова: культура мира, пацифизм, альтернативная служба, меннониты, российское государство.

Введение. Российский пацифизм, как составляющая «культуры мира», является одной из наиболее изученных современными культурологами, философами, религиоведами, историками проблем. Как правило, отмечается присущий христианской доктрине пацифизм, определяющий его религиозную составляющую в различных конфессиях и религиознофилософских движениях в XVI-XX вв. - православия, европейского протестантизма (меннониты, баптисты, евангельские христиане и др.), групп старого русского сектантства (духоборов, трезвенников), толстовства и проч. [Клибанов 1965, Илюхина 1992; Гусейнов и др. 1993; Долгий путь... 1997; Мелешко 2006, Стволыгин 2010; Безносова 2014; Назарова, Редькина 2018]. Одной из религиозных групп, внесших значительный вклад в становление и развитие «культуры мира», стали меннониты, практиковавшие демократический уклад жизни по образу ранней христианской общины, неприятие всех форм насилия (в том числе военного). Основатель общины Менно Симонс (1495-1561 гг.) учитывал опыт Мюнстерской коммуны и полагал, в отличие от анабаптистов Германии, Швейцарии («носящих меч»начавших силой оружия Страшный Суд как преддверие воцарения на земле Царства Божьего), что построить силой Царство Божие на земле нельзя; христианам нужно жить как представителям этого Царства, согласно его законам [Санников (ред.) 2012, 203-233]. Ра- венство, братство, любовь к ближнему, взаимопомощь с единоверцами и в целом с окружающим сообществом, трудолюбие (труд как молитва, спасение делами), отказ от излишеств в пище, одежде, развлечениях; личное поведение, основанное на христианских заповедях, строгая поведенческая дисциплина были основными кодами культуры меннонитов, основанной на Библии (Нагорной проповеди Иисуса Христа) [Санников (ред.) 2012, 335-387, 415-425, 427-431]. Особенностью меннонитов было восприятие своей религиозной общины как сообщества избранных христиан - сторонников святой жизни, что предполагало вступление в брак исключительно с единоверцами. В результате на протяжении веков в Голландии, Пруссии и других немецких землях, а также в России сложилась определенная этноконфессиональная общность, к основным культурным чертам которой нужно отнести христианскую веру, основанную на Библии, использование Библии на немецком языке, язык - платтдойч (диалект немецкого языка). Меннониты в хозяйственной деятельности предпочитали заниматься сельским хозяйством (как угодным Богу промыслом, определенным в Библии) и связанными с ним производствами. Осознанный и четко защищаемый меннонитами в XVII-XX вв. пацифизм приводил к тому, что меннониты были вынуждены регулярно бежать из тех государств, где власти начинали принуждать их ко 
вступлению в армию, к выполнению повинностей в пользу армии, выплате военных налогов и проч. В результате общины меннонитов мигрировали по миру, расселились не только в Голландии (родина меннонитов), но и в Пруссии (позже - Германии), Австро-Венгрии, США, Канаде и проч.

В 2019 г. исполнилось 230 лет с момента переселения меннонитов в Россию по приглашению российских властей. Культура меннонитов в Российской империи, история развития социальной и церковной жизни, отстаивание меннонитской этноконфессией своих прав на сохранение пацифистских убеждений и образа жизни, борьба с российскими властями в эпоху Великих реформ 1870-х гг., эмиграция по пацифистским убеждениям из России в Северную Америку в конце XIX в., законодательное признание альтернативной службы меннонитов в лесных командах, подчиненных Лесному (а не военному) ведомству, служба в лесных командах регулировалась Лесным, а не Воинским уставом - все эти вопросы всесторонне изучены отечественными и зарубежными религиоведами и историками [Кто такие меннониты... 1915; Бондарь 1916; Клибанов 1965; Крестьянинов 1967; Берестень 2000; Венгер 2009; Стволыгин 2010; Безносова 2014; Назарова, Редькина 2018; Erokhina 2019]. Однако вне внимания исследователей остаются как постепенные перемены в пацифистских убеждениях меннонитов, которые происходили на российской почве, так и причины такой трансформации.

Трансформация идей пацифизма меннонитов в условиях Российской империи. В условиях российского государства, по мнению авторов, происходит трансформация идей пацифизма, присущего европейским протестантам, в частности меннонитам, которые стали первой в истории Российской империи религиозной группой, добившейся от властей признания права на соблюдение их прав на сохранение антивоенных убеждений - базовой конфессиональной и этнокультурной чертой меннонитской общины. Екатерина II, приглашая иностранцев для внутренней колонизации пустующих территорий Новороссии во второй половине XVIII в., даровала им свободу вероисповедания, широкие льготы. В 1789 г. начинается переселение меннонитов из Пруссии в Причерноморье (Екатеринославскую, Таврическую и Херсонскую губернии). В дальнейшем и Александр I гарантировал меннонитам не только свободу веры (и в том числе - освобождение от воинской повинности, постоя войск, налоговых выплат, связанных с содержанием армии и прочими военными расходами). Учитывая зажиточность меннонитской общины (переезжали, имея в запасе денежный капитал, скот, сельскохозяйственные орудия и проч.), большой опыт ведения передового для своего времени аграрного производства в сложных природно-климатических условиях (в частности в болотистой местности в Пруссии), российское государство обеспечило меннонитов значительным земельным наделом - 60-65 десятин на двор, закрепило за ними ряд важных привилегий по ведению хозяйства (освобождение от налогов на ряд лет, питейные откупа и пр.), каких меннониты не имели ни в одном государстве Европы в XVIII-XIX веках. Все это создало серьезную базу для быстрого материального укрепления меннонитской этноконфессии, роста численности населения в материнских колониях под сенью поддержки властей в Причерноморье, Поволжье; позже - дочерних колоний в Крыму, Сибири, Средней Азии, на Северном Кавказе, где также сохранялся религиозно-бытовой уклад, основанный на пацифистских убеждениях. Средняя численность детей в меннонитских семьях достигала 10-12 детей.

Нарушило благополучие этноконфессии проведение военной реформы в 1874 г., которой вводилась всеобщая воинская повинность. Часть консервативно настроенных меннонитов эмигрировала в Канаду, сохранив связи с российской общиной. Однако большая часть общин не хотела покидать гостеприимную Россию, где они прожили абсолютно спокойно. После упорной борьбы меннонитам удалось найти компромисс с государством, добившись признания последним прав этноконфессии на альтернативную службу, о которой говорилось выше. Серьезным испытанием для общины стал раскол на церковных и братских меннонитов по ряду догматических вопросов. При этом пацифизм остался непоколебимой частью вероучения обеих групп [Бондарь 1916; Клибанов 1965; Крестьянинов 1967; 
Берестень 2000; Венгер 2009; Стволыгин 2010; Безносова 2014; Назарова, Редькина 2018; Erokhina 2019]. По нашему мнению, важно подчеркнуть, что и церковные, и братские меннониты всей империи регулярно участвовали в съездах, решавших проблемы по их содержанию лесных команд, что сплачивало конфессию, несмотря на внутриконфессиональные разногласия. Такая практика не была характерна для других регионов проживания меннонитов за пределами Российской империи.

С другой стороны, в условиях российской действительности, наблюдалась постепенная трансформация отдельных составляющих пацифистских установок меннонитов. Источником, который детально характеризует участие меннонитов в войнах российского государства в XIX - начале XX в., стал сборник документов и материалов «Кто такие меннониты. Краткий исторический очерк», составленный членом Государственной Думы меннонитом П.Я. Брауном. Труд был опубликован протестантским издательством Радуга (Гальбштадт Таврической губернии) в 1915 году. Издательство занималось серьезной просветительской работой в России, в том числе и пропагандой идей пацифизма [Назарова, Редькина 2019]. Сборник вышел в свет в начале Первой мировой войны, стал попыткой меннонитов оградить общину от антигерманской кампании 1914-1915 гг., от распространения на этноконфессию действия ликвидационных законов по отношению к российским немцам. В связи с этим данный труд должен был доказать российскому обществу, что меннониты - потомки голландцев, прибыли в Россию по приглашению властей, проживали в империи свыше ста лет и зарекомендовали себя как благонадежные граждане. В сборник вошли документы российских архивов, коллекций документов и архивов меннонитских общин Причерноморья, которые доказывали активное и разностороннее участие меннонитов в благотворительных акциях в пользу русской армии. В частности, упоминались сборы средств в пользу инвалидов Русско-турецкой войны в 1828-1829 гг.; пожертвования для русского корпуса, направлявшегося в Европу на подавление революционного движения в 1848 году. Большую поддержку русской армии ока- зали меннониты Таврической губернии в ходе Крымской войны: собирали средства на содержание полевых госпиталей, на уход за ранеными воинами; выделяли транспорт, провиант, фураж для русской армии безвозмездно и за плату. Сохранились сведения об аналогичных акциях в годы русско-японской войны и т. д. [Кто такие меннониты... 1915, 58-71].

Меннониты сопровождали свою благотворительность в пользу армии выражением своих глубоких чувств неизменной приверженности к императорскому престолу, любви к закону и порядку в специальных посланиях в адрес высших властей. В свою очередь, императоры Николай I, Александр II, министры, губернаторы, генералы и проч. также выражали благодарность меннонитам за патриотизм, проявленный в военные годы [Кто такие меннониты... 1915, 63]. Сборник документов 1915 г. сохранил на своих страницах свидетельства о благонадежности и верности меннонитов императорскому дому. В основном архивы этноконфессии в Таврической, Екатеринославской и Херсонской губерниях, доказывающие высокую оценку патриотической позиции меннонитов со стороны российского государства, погибли в огне гражданской войны в 1917-1921 гг. на Украине и в Крыму.

Таким образом, для меннонитов, проживавших в Российской империи, понимание патриотизма было сопряжено с осознанием необходимости защиты интересов обретенной Родины, посильной материальной помощи ее армии, всемерной поддержки раненым воинам. На наш взгляд, в условиях российского государства произошло определенное влияние на меннонитскую этноконфессию православного понимания пацифизма и патриотизма [Святые отцы...; Священное Писание о войне...]. В годы Первой мировой войны, некоторые меннониты посчитали для себя возможным служение в санитарных ротах, что также свидетельствует о значительной трансформации представлений о пацифизме в российском обществе в условиях военного времени. Меннонитские предприниматели Юга России, ориентированные до 1914 г. на выпуск продукции сельскохозяйственного машиностроения, не стали отказываться от государственных военных заказов, принимали активное участие в снабжении русской армии. 


\section{НАУЧНЫЕ СООБЩЕНИЯ}

Еще одним важным свидетельством об изменениях во взглядах меннонитов на вопрос о том, что допустимо в рамках пацифистской доктрины, стал вопрос о владении оружием. Документы департамента духовных дел иностранных исповеданий МВД Российской империи свидетельствуют о широком распространении среди меннонитов Екатеринославской и Таврической губерний в 1915 г. владения оружием - коллекционным, спортивным, охотничьим - ружьями, винтовками, револьверами, реже - саблями и другим колющережущим оружием. Списки включают фамилии и точный перечень оружия, изъятого у меннонитов Александровского, Бахмутского, Верхнеднепровского, Екатеринославского, Павлоградского уездов Екатеринославской губернии, Гнаденфельдской и Гальбштадской волостей, район пристава 6-го стана Мелитопольского уезда Таврической губернии, г. Кизляр. Кроме того, список без точного указания места жительства меннонитов. Оружие изымалось властями не только у граждан, но и у меннонитских организаций, сельских обществ [Список меннонитов... 1915].

Как уже выше отмечалось, большинство меннонитов в начале XX в. проживало в сельской местности, занималось охотой. Кроме того, семьи и общества нуждались в охране личности и имущества. С другой стороны, меннониты, проживавшие в городах, также владели оружием (чаще всего револьверами), имели даже оружейные магазины. В списках меннонитов, у которых в 1914-1915 гг. было изъято оружие, как правило упоминались мужчины и 5 женщин, владевших оружием (2 из них вдовы). Массовое наличие оружия у меннонитов Причерноморья говорит и о широко распространенной практике умения владеть им, что, по нашему мнению, говорит о переменах в менталитете представителей этноконфессии, в том числе и меннониток, позволяет более подробно представить специфику этнокультурной и хозяйственной деятельности меннонитской общины в Российской империи. Владение огнестрельным оружием, наличие значительных арсеналов в меннонитских общинах приведет к созданию отрядов самообороны в годы гражданской войны на Украине и в Крыму. Незначительная часть меннонитов воевала с оружием в руках как на стороне белых, так и в рядах красных (единицы). Большая часть, оставшаяся в Советской России, воспользовалась правом не служить в армии по религиозным убеждениям, закрепленном декретом СНК РСФСР от 4 января 1919 года.

\section{Заключение}

Подводя итог, можно констатировать, что в условиях российского государства происходила постепенная трансформация отдельных сторон пацифистской доктрины меннонитов под влиянием новых условий ведения хозяйства в малозаселенных и труднодоступных регионах империи. Понимание своих обязанностей перед государством, приютившим гонимую общину, давшем ей защиту свободы вероисповедания и широкие материальные льготы, порождал и новое отношение к национальным интересам России, к ее армии, воинам, защищавшим Отчизну; желание внести лепту в посильной форме, которая не нарушала бы серьезно базовый пацифистский принцип этноконфессии - отказ от воинской повинности. Вероятным представляется влияние православных взглядов на справедливые войны, на сущность служения Отечеству на патриотические взгляды меннонитов Причерноморья. Нежелание покидать Россию в 1870-х гг. после введения всеобщей воинской повинности стимулировало меннонитов к поиску компромисса с российским государством, привело к возникновению альтернативной службы для них в лесных командах. О трансформации отдельных сторон пацифистских убеждений меннонитов, проживавших в Новороссии, говорит широкое владение холодным и огнестрельным оружием, которое было изъято у них в 1914-1915 годах. Экстремальные условия Первой мировой и гражданской войн дали толчок к более активному пересмотру пацифистских убеждений меннонитами, к индивидуальным решениям о формах служения в армии или отказе от нее.

\section{ПРИМЕЧАНИЕ}

${ }^{1}$ Исследование выполнено при финансовой поддержке РФФИ в рамках научного проекта № 1809-00574 «Меннониты в социально-экономическом и культурном развитии Причерноморья». 
The study was conducted with the financial support of RFBR, project no. 18-09-00574 "The Mennonites in the socio-economic and cultural development of the Black Sea region".

\section{СПИСОК ЛИТЕРАТУРЫ}

Безносова 2014 - Безносова О. Екатеринославская губерния - Terra Incognita евангельского движения в Российской империи (середина XVIII в. - 1917 г.): монография. Steinhagen: Samenkorn, 2014.

Берестень 2000 - Берестень Ю.В. Организация и становление альтернативной службы меннонитов в лесничествах царской России во второй половине XIX - начале XX вв. // Вопросы германской истории. Днепропетровск: Издво Днепропетр. ун-та, 2000. С. 80-99.

Бондарь 1916 - Бондарь С.Д. Секта меннонитов в России (в связи с историей немецкой колонизации на юге России). Петроград: Тип. В.Д. Смирнова, 1916.

Венгер 2009 - Венгер Н.В. Меннонитская промышленность в условиях модернизации Юга России: между конгрегацией, кланом и российским обществом (1789-1920). Днепропетровск: Изд-во Днепропетр. нац. ун-та, 2009.

Гусейнов и др. 1993 -Гусейнов А.А., Степин В.С., Госс Ж., Холис Р. Ненасилие: философия, этика, политика. М.: Наука, 1993.

Долгий путь... 1997 - Долгий путь российского пацифизма: Идеал международного и внутреннего мира в религиозно-философской и общественно-политической мысли России. М.: ИВИ РАН, 1997.

Илюхина 1992 - Илюхина Р.М. Российский пацифизм вчера и сегодня. М.: ИВИ, 1992.

Клибанов 1965 - Клибанов А.И. История религиозного сектантства в России (60-е гг. XIX в. 1917 г.). М.: Наука, 1965.

Крестьянинов 1967 - Крестьянинов В.Ф. Меннониты. М.: Политиздат, 1967.

Кто такие меннониты... 1915 - Кто такие меннониты: крат. ист. очерк. Гальбштадт: Радуга, 1915.

Мелешко 2006 - Мелешко Е.Д. Христианская этика Л.Н. Толстого. М.: Наука, 2006.

Назарова, Редькина 2018 - Назарова Т.П., Редькина О.Ю. Меннониты Крыма в отечественной историографии // Мировые научно-технологические тенденции социально-экономического развития АПК и сельских территорий: материалы Междунар. науч.-практ. конф., посвящ. 75-летию окончания Сталинградской битвы (г. Волгоград, 31 янв. -2 февр. 2018 г.).
Т. 5. Волгоград: ФГБОУ ВО Волгоград. ГАУ, 2018. С. 65-70.

Назарова, Редькина 2019 - Назарова Т.П., Редькина О.Ю. Религиозно-просветительская деятельность протестантов Причерноморья: на примере меннонитского издательства «Радуга» (1908-1920 гг.) // Научная мысль Кавказа. 2019. № 2. С. 63-68.

Санников 2012 (ред.) - Санников С.В. (ред.). Менно Симонс и анабаптисты. Steinhagen: Samenkorn, 2012.

Святые отцы... web - Святые отцы церкви о войне и воинском служении [Православие.ru] // http://www.pravoslavie.ru/jurnal.

Священное Писание о войне... web - Священное Писание о войне и воинском служении [Православие.ru] // http://www.ravoslavie.ru/ jurnal.

Списки меннонитов... 1915 - Списки меннонитов, у которых отобрано оружие // Российский государственный архив. Департамент духовных дел иностранных исповеданий Министерства внутренних дел. Ф. 821. Оп. 133. Раздел. Сектанты. Д. 322.

Стволыгин 2010 - Ствольгин К.В. Отказы от военной службы вследствие убеждений в Российской империи. Минск: РИВШ, 2010.

Erokhina 2019 - Erokhina O.V. Forest Teams as an Alternative Service of the Mennonites in the Russian Empire Until 1914. Вестник Волгоградского государственного университета. Серия 4, История. Регионоведение. Международные отношения. 2019. Т. 24, № 3. С. 68-78.

\section{REFERENCES}

Beznosova O., 2014. Yekaterinoslav Province-Terra Incognita of the Gospel movement in the Russian Empire (mid-18 $8^{\text {th }}$ century - 1917): monograph / under the general. ed. Victor Fast. Steinhagen, Samenkorn.

Beresten Yu.V., 2000. Organization and establishment of an alternative Mennonite service in the forest districts of Tsarist Russia in the second half of the $19^{\text {th }}$ and early $20^{\text {th }}$ centuries. Questions of German history. Dnepropetrovsk, Publishing house of Dnepropetr. Univ., pp. 80-99.

Bondar S.D., 1916. Mennonite sect in Russia (in connection with the history of German colonization in southern Russia). Petrograd, Printing house V.D. Smirnova.

Wenger N.V., 2009. Mennonite industry in the modernization of the South of Russia: between the congregation, the clan and Russian society (1789-1920). Dnepropetrovsk. 
Huseynov A.A., Stepin V.S., Goss Zh., Holmes R., 1993. Non-violence: philosophy, ethics, politics. Moscow, Nauka.

A long way of Russian pacifism: The ideal of the international and domestic world in the religious, philosophical and socio-political thought of Russia, 1997. Moscow, IVI RAS, 1997.

Ilyukhina R.M., 1992. Russian pacifism yesterday and today. Moscow, IVI.

Klibanov A.I., 1965. History of religious sectarianism in Russia (60s of the 19 $19^{\text {th }}$ century - 1917). Moscow, Nauka.

Krestyaninov V.F., 1967. Mennonites. Moscow, Politizdat.

Who are the Mennonites: a brief historical outline, 1915. Halbstadt, Rainbow.

Meleshko E.D., 2006. Christian ethics of L.N. Tolstoy. Moscow, Nauka.

Nazarova T.P., Redkina O.Yu., 2018. Mennonites of Crimea in Russian historiography. World scientific and technological trends in the socioeconomic development of the agro-industrial complex and rural territories: proceedings of the International Scientific and Practical Conference dedicated to the $75^{\text {th }}$ anniversary of the end of the Battle of Stalingrad (Volgograd, January 31 - February 2), vol. 5. Volgograd,
FSBEI VO Volgograd State Agrarian University, pp. $65-70$.

Nazarova T.P., Redkina O.Yu., 2019. Religious and educational activities of the Protestants of the Black Sea: the example of the Mennonite publishing house "Rainbow" (1908-1920). Scientific Thought of the Caucasus, no. 2, pp. 63-68.

Sannikov S.V. (ed.), 2012. Menno Simons and the Anabaptists. Steinhagen, Samenkorn.

The Holy Fathers of the Church on War and Military Service [Pravoslavie.ru]. URL: http:// www.pravoslavie.ru/jurnal.

The Holy Scripture about the war and military service [Orthodoxy.ru]. URL: http://www.ravoslavie.ru/ jurnal.

Lists of Mennonites whose weapons are taken away, 1915. Russian State Archive. Department of Spiritual Affairs of Foreign Confessions of the Ministry of the Interior. F. 821. Op. 133. Section. Sectarians. D. 322.

Stvolygin K.V., 2010. Refusals from military service due to beliefs in the Russian Empire. Minsk, RIVSH.

Erokhina O.V., 2019. Forest Teams as an Alternative Service of the Mennonites in the Russian Empire Until 1914. Science Journal of Volgograd State University. History. Area Studies. International Relations, vol. 24, no. 3, pp. 68-78.

\section{Information about the Authors}

Olga Yu. Redkina, Doctor of Sciences (History), Professor, Department of International Relations, Political Science and Regional Studies, Volgograd State University, Prosp. Universitetsky, 100, 400062 Volgograd, Russian Federation, redkina@volsu.ru, https://orcid.org/0000-0002-8978-9575

Tatjana P. Nazarova, Candidate of Sciences (History), Associate Professor, Department of Philosophy, History and Law, Volgograd State Agrarian University, Prosp. Universitetsky, 26, 400002 Volgograd, Russian Federation, hist_tatyana@mail.ru, https://orcid.org/0000-0003-1701-9237

\section{Информация об авторах}

Ольга Юрьевна Редькина, доктор исторических наук, профессор кафедры международных отношений, политологии и регионоведения, Волгоградский государственный университет, просп. Университетский, 100, 400062 г. Волгоград, Российская Федерация, redkina@volsu.ru, https://orcid.org/0000-0002-8978-9575

Татьяна Павловна Назарова, кандидат исторических наук, доцент кафедры философии, истории и права, Волгоградский государственный аграрный университет, просп. Университетский, 26, 400002 г. Волгоград, Российская Федерация, hist_tatyana@mail.ru, https://orcid.org/0000-0003-1701-9237 